\title{
COLLOQUAIL, SLANG AND TRANSFORMATIONAL LANGUAGE: COMPERATIVE STUDY
}

\author{
Suhardianto. Universitas Putera Batam \\ Suhardiantogamya@gmail.com
}

Fasaaro Hulu. Universitas Putera Batam

fashulu@gmail.com

\begin{abstract}
Abstrak
Penelitian ini bertujuan untuk menemukan perbandingan tentang bagaimana masingmasing bahasa (colloquail, slang, transformasional) dibentuk, dalam konteks apa digunakan, dan perspektif yang digunakan oleh ketiga bahasa ini. Penelitian ini menggunakan penelitian deskriptif kualitatif. Pada tahap penyediaan data, peneliti menggunakan teknik Simak dan Cakap. Dalam proses analisis data, para peneliti menggunakan metode padan dan metode agih. Metode agih digunakan untuk melihat konstruksi bahasa slang di setiap periode sedangkan metode padan digunakan untuk menggambarkan Perspektif remaja dalam penggunaan bahasa sehari-hari, bahasa slang dan bahasa transformasional dari waktu ke waktu. Hasil penelitian menunjukkan bahwa cara ketiga bahasa non standar berbeda satu sama lain. Bahasa colloquail dibentuk dengan mengubah "a" menjadi " $e$ " pada suku kata akhir, Penghapusan suku kata pertama, pembentukan kata baru, suku kata tambahan "nge", mengubah "a" menjadi " $e$ " pada suku kata akhir dan menambahkan "an", dan Partikel tambahan "deh", "aja", "kok", "ama". Bahasa slang dibentuk oleh Initial Setiap Kumpulan Kata, kata yang dipilih, Penghapusan huruf awal dan suku kata, Perubahan "s 'menjadi" c ", Perubahan" $k$ "menjadi" $q$ ", Perubahan" au "menjadi" $w$ ", Perubahan "u" menjadi "oe", Adopsi kata-kata dasar, singkatan bahasa Inggris, Abreviasi Inggris-Indonesia, Kutipan dan konstruksi kata baru. Bahasa terjemahan dibentuk oleh rumus Ga, Gi, Gu, Ge, Go setelah bunyi vokal tunggal suku kata, rumus $G a / G, G i, G u, G e$, Go sebelum suku kata bunyi dipthong, rumus Ga, Gi, $\mathrm{Gu}, \mathrm{Ge}$, Go sebelum bunyi konsonan terakhir, dan rumus Ga, Gi, Gu, Ge, Go untuk konsonan gugus. Konteks penggunaan bahasa sehari-hari lebih dipengaruhi oleh aspek kebiasaan yang didengar oleh pembicara di lingkungan mereka seperti di rumah, di pasar, taman bermain, dan acara-acara tertentu lainnya. Penggunaan bahasa slang dipengaruhi oleh lingkungan komunitas remaja di mana pengguna hanya berusia 12 sampai 19 tahun. Bahasa transformasional dipengaruhi oleh keinginan untuk menyembunyikan pembicaraan kepada orang-orang yang bukan dari kelompok mereka seperti orang tua dan orang asing.
\end{abstract}

\section{Kata kunci: Bahasa Sehari-hari, Bahasa Slang, Bahasa Transformasional}

\section{INTRODUCTION}

Slang, colloquail and tranformational are group of informal language that mostly used by someone in communication. slang is mostly used among teenagers while colloquail and transformational language mostly used in informal situation by everyone in the daily communication. Slang language is language of particular group, trade or persuit or an informal non-standard vacabulary changed word and extravagant, forced or facetious figures of speech. Colloquail language is a words or phrases that are only used in

Utterances in spoken language. It used in casual conversation. Education native speakers of a language normally use colloquial speech in informal situation with friends, fellow workers and members of the family. (Trask, 2001)

A Phenomena of slang, colloquail and transformational language happened and used in many countries. Both of them expand and spread in all aspect of language used such as familiy, school, community and other formal situation. Due to the use of slang, colloquail and 
transformational language used at any time and places, it needs to do the research about the colloquial, slang and transformational language to get more understanding and knowledge how the slang, colloquial and transformational language constructed, context influenced, and perspective of used.

The development of research on colloquial, slang and transformational language is considered important given the widespread use of colloquial, slang and tranformational languages in all aspects of language use from time to time. The use of the three languages has spread massively in all aspects of communication both oral and written. In the oral aspect, the three languages are used in all communities directly in daily life in the midst of society. Whereas in the written aspect, the three languages have expanded in all domains of language use such as social media (Facebook, twitter, instagram, whatsapp, blackberry messager, movie) and write like (articles, magazines, memos, news papers).

The use of colloquial, slang and transformational languages has the potential for destruction of the stadard language used. This is because teenagers who are the nation's generation should be able to maintain and preserve the standard language but destroy it by creating a new language Non-standard or standard language varied form and sound. Broadcasting the widespread use of slang may result in mixed use of standard and non-standard languages in a domain of the use of language especially in the formal sphere. Another worse thing to worry is that people are no longer able to distinguish the use of the three languages in community life so that it affects the personality of someone in interacting with them.
The results of this study are expected to prevent the use of three languages that is increasingly massive and can damage the standard language. Knowing the form, context, and perspective of use is considered important in supporting the results of previous research and to know more in depth about the variation of steps taken by people from time to time in forming the three languages, so that the results can be compared to find the bright spot of the presence of three languages in any given era or period so that precautions can be taken in the use of three languages that undermines the use of standard language.

Related to the description of three informal languages above can be concluded that the use of three informal languages massively happened and applied in any aspect of language used. Based on this phenomenon, the researchers are interested in finding out deeply the forms, context of used and perspective of used of three informal languages mentioned above.

\section{REVIEW OF RELATED LITERATURE}

\subsection{Language Style}

The variation of language use is determined by the aim of language use and refers to the users. The use of language is influenced by the place where the language used, users who and whom the language used. Language style is divided into two; formal and informal language style. Informal language style is a language used in a friendship domain with the speakers like friends. Formal language style is a language used in a formal domain with the higher social status speakers. (Inayati, 2014)

From the explanation above, it is concluded that slang is one of the informal 
languages which is used by the teenagers in their group. Slang is used in community informally which involves the coeval friendship.

\subsection{Colloquial Language}

In daily activity has conversational language. Generally, colloquial style is not really attention to pronunciation, choice, or words, or sentence structure. Colloquial is words or phrases that are only used in utterances in spoken language. It used in casual conversation. Education native speakers of a language normally use colloquial speech in informal situation with friends, fellow workers and members of the family. (Trask, 2001)

The same opinion about colloquial language is also defined as an informal language that normally applied in daily communication in society. The use of colloquial language is assumed by people to get easier and simpler in doing communication among them. (Sato \& Kim, 2012)

\subsection{Slang}

Slang is used to communicate informally in a particular group such as teenagers, army, group singer, etc. The vocabulary of slang used is known by the speakers in the community. In other words, slang is defined by the speakers in the community. Slang is not nearly found in the dictionary. Slang is almost the same with idiom used in informal communication. (Pal \& Saha, 2013)

Traditionally, slang is known as vulgar and rude language. Slang is reflected as an impolite language in society. Linguistically, slang is prohibited in use in society in a formal way. Slang is one of the language styles used by the teenagers to express themselves in using language and developed to the need of communication (Zhou, Yanchun, 2013).
There are some factors the use slang of slang among teenagers (Suhardianto, 2016),

1. Being cool

2. updated

3. easy to communicate with coeval

4. following friends

5. being joked

6. being popular

7. habitual

\subsection{Meaning of Slang}

The meaning of words in slang is determined by the contextual meaning. Analyzing from the dictionary, the meaning of words in slang is only taken from the native slang speaker. The words of slang are known by the group itself. Slang is a language which is recognized the form but not understood. (Epoge, 2012)

\section{RESEARCH METHOD}

This research belongs to the qualitative research where the researcher becomes the main instrument in defining the research analysis process without involving the numbers as the instrument. The population of the research is 12 sub-districs which are indicated exist in Batam and consist of teenagers's community. The indicator of teenager's age as the subjects or informants of the research is about twelfth to nineteen years old. These informants refers to the slang and colloquial language use. Meanwhile, for the transformational language, the informants of the research are indicated as a young at the year of 1980 or 1990. Approximate age is 40-45 years old today.

In taking the sample the researcher focused on 3 sub-districts that exist in Batam such as Batu Aji, Tiban and Batam Center. The researcher collected 45 informants from three sub-districts. Each sub-district are taken 15 informants purposively. 
In analyzing the data, the researchers use of Padan and Agih Method. The Padan method will categorize the main element pragmatically. Meanwhile, Agih method explore the data analyze the construction of the word itself.

\section{ANALYSIS AND FINDING}

In this chapter the researchers will perform the process of analyzing the collected data to find the comparison of forms, context and perspective of colloquail, Slang and transformational language.

\subsection{An Analysis and Finding of Colloquail,} slang and Transformational Language in Formation and Context

In this section, the researchers will describe the comparison of forms, contexts, and perspectives of colloquial, slang and transformational language found in Batam. Data were collected from several areas in the city of Batam, among others, in Batu Aji, Tiban and Batam Center.

\subsubsection{Colloquial Language}

As one of the non-standard languages, colloquial language does not pay much attention to pronunciation, choice of words, or sentence structure. Everyday language is an expression commonly used only in a speech in spoken language. Native speakers of the language usually use everyday language in an informal situation with friends, colleagues and family members. Here are the data collected to see the form, context, and use of everyday language.

Data (1)

Jim, gue boleh main ke rumah ntar malem? bentar aja!

(Rin, may I go to your house tonight? Just for a while!)

From example (1) above, the word gue, malem, and bentar are belong to colloquial words, which means I, tonight and a while in English language. These words are mostly used by people in daily communication. The conversation normally takes in informal situation and conveyed to an intimate person

Data (2)

Sorry banget, Gak ada jajanan maklum hidup sendiri

(I am So Sorry for having not food )

From example (2) above, the word gak, jajanan, and banget are colloquial words. The word banget refers to something special to express. Gak refers the meaning of negation or has no something. The word jajanan means refers to to the food or something that can be given to others for eating.

Data (3)

Gue ngerasa dia agak beda sama gue (I feel he behaves differently )

From example (3), the word ngerasa is defined as colloquial word, which means to feel in English language. This word better not to use in formal speaking because this word is not depend on standard language.

Data (4)

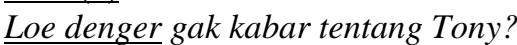
(do you heard about Tony)

From example (4) above, the word loe and denger are also defined as colloquial words. The word Loe refers to "you" in English and the word denger refers to something someone listening. These words are used by someone in informal situation, for example with friend or someone who has the same level of age with the speaker.

Data (5)

Gue dapat Balesan surat dari dia (I got a letter from him)

From example (5) the word balesan is colloquial word, it means receiving something in English language. This word occur in informal conversation because it is not standard language.

Data (6) 
Loe tambahin dikit aja bumbunya pasti laku kok

(Add the flavour, it will be oke)

From example (6), the word dikit and aja, are colloquial word, it means little and only in English language. The word dikit basically comes from the normal word sedikit. Teenagers delete the first syllable "se" and comes "dikit". The word "aja" also formed by deletion the letter "s".

Data (7)

Dia nyesel ngobrol ama ceweknya (He regerets ever talked to his girl friend)

From example (7), the word nyese and ngobrol are colloquial word, it means to regret and speak with in English language. This word used by teenagers in informal situation.

Data (8)

Jhon, gimana kabarmu? Udah lama gak ketemu ya.

(Jhon, how are you? Long time no see you)

From example (8), the word gimana and gak are colloquial word. The word gimana means how in English language. The word gimana is non-standard word word that usually used in informal situation and informal conversation.

Data (9)

Gak usah cemas deh

(Don't worry)

From example (9), the word gak usah are colloquial word, which means not necessary in English language. This used by teenagers in informal situation, with friends and family. This words is style from teenagers in informal conversation.

Data (10)Bener ya, kamu gak apa-apa duduk sendirian disana?

(All right, it's oke leaving you sitting alone here?)

From example (10) above, the word bener and gak are colloquial word, which means right and no in English language. This used by teenagers in informal conversation. This word better not to use in informal situation because this word is not depend on standard language.

Data (11)

Gimana kalau kamu dulu yang cerita tentang dirimu

(Why don't you start to tell me the history about yourself)

From the example (11), the word gimana is colloquial word, which means ho in English language. This word better not to use in formal speaking or writing, because this word is notdepend on standard language

Data (12)

Gue gak benci kok sama lu

(I don't hate you)

From example (12), the word gue means aku in Indonesia language and I in English language, and gak is colloquial word which means no in English language. This word used by teenagers in informal situation.

Data (13)

Dia udah lewat

(He has passed)

From example, the word udah are colloquial word, it means already in English language. This word used by teenagers in informal conversation with their friend or family.

\subsubsection{Slang Language}

Slang is a non-formal language commonly used by teenagers in their community. In this section, the researchers analyzed the data categorized as slang language. as the language of the adolescent community, slang is formed in several ways:

Data (14)

Initial Each Word Collection:

$G P L$ is created from the abbreviation of Gak Pakai Lama

$\underline{G R}$ is created from the abbreviation of $\underline{\text { Gede }}$ Rasa

$P J$ is created from the abbreviation of Pajak Jadian

HTS is created from the abbreviation of Hubungan Tanpa Menikah 
$\underline{S M S}$ is created from the abbreviation of

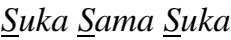

Data (15)

Initial Syllable Collection:

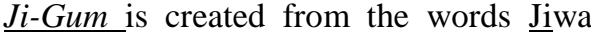
Guncang

$\underline{\mathrm{Cu}-M i}$ is created from the words $\underline{\mathrm{Cu}} \mathrm{ma}$ Minjam

$\underline{\mathrm{Ca}-\mathrm{Per}}$ is created from the words $\underline{\text { Cari }}$ Perhatian

$\underline{C e-M a t}$ is created from the words Cewek Matre

Data (16)

Word letter choosen:

The worrd slang "Org" is created from the word Orang. The form of this slang is done by choosing some letters in a word $O, R, G$ and becomes $\mathrm{Org}$. This word refers to kind of human or people in English.

From the description above can be conclude that the teenagers communicate using slang language by abbreviating of initial each word, initial syllable collection and word letter choosen. The next slang language is created by teenagers by deleting some letters to make slang language as discussed below:

Data (17)

Deletion of initial letter and syllable

The word " $G i$ " is created from the word

Lagi. To make slang the teenagers delete the syllable $\underline{\mathrm{La}}$. It becomes $\underline{\mathrm{Gi}}$ for slang that refers to the meaning of Lagi to ask about kind of activity done by someone not asking about additional for something

Example: Loe gi apa?

*Loe mau gi

Another slang word is the word $\underline{P a}$ which is created from the word Apa. To make slang the teenagers delete the letter $\underline{A}$. It becomes $\underline{\mathrm{Pa}}$ for slang that refers to the meaning of Apa to ask about someone's need not asking about someone's activities
Example: Mau pa coy?

*Lagi pa coy? (Unaccepted)

The next slang form is " $Y$ " which is created from the word Iya. To make slang the teenagers delete the letter $\underline{I}$. It becomes $\underline{Y a}$ for slang that refers to the meaning of $\underline{I y a}$ to ask either about someone's need and activities.

Example: Loe mau ya? Loe gi apa $y a$ ?

The next slang language forms is about the forms of slang language that are created by changing of letters. It can be seen from the discussion below:

Data (18)

Change of " $S$ " to letter " $C$ "

The word Makacih is a replacement of the word Makasih or Terima Kasih. To make slang language the teenagers change the letter " $\mathrm{S}$ " to the letter "C" as example below:

Example: Makacih

Makasih/Terima Kasih

The word Kacian is a replacement of the word kasihan. To make slang language the teenagers change the letter " $\mathrm{S}$ " to the letter " $\mathrm{C}$ " as example below:

Example: Kacian

Kasihan

The word Cayang is a replacement of the word Sayang. To make slang language the teenagers change the letter " $\mathrm{S}$ " to the letter " $\mathrm{C}$ " as example below:

Example: Cayang < $\quad \underline{\text { Sayang }}$

The word Clamanya is a replacement of the word Selamanya. To make slang language the teenagers change the letter " $\mathrm{S}$ " to the letter "C" as example below:

Example: Clamanya <

Selamanya

The word $\underline{\text { Clalu }}$ is a replacement of the word Selalu. To make slang language the teenagers change the letter " $\mathrm{S}$ " to the letter " $\mathrm{C}$ " as example below: 
Example: Clalu

Selalu

Data (19)

Change of " $K$ " to letter " $Q$ ",

The word $Q m u$ is a replacement of the word $\underline{K a m u}$. To make slang language the teenagers change the letter " $\mathrm{K}$ " to the letter "Q" as example below:

\section{Example: $Q m u$}

Kamu

Change of "Ia" to sound "Y" as discussed below:

The word $\underline{D y}$ is a replacement of the word Dia. To make slang language the teenagers change the sound "Ia" to the sound "Y" as example below:

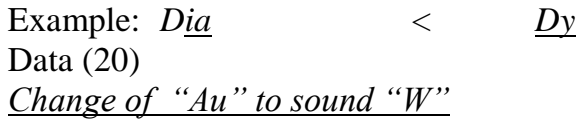

The word $\underline{T w}$ is a replacement of the word $\underline{T a u}$. To make slang language the teenagers change the sound "Au" to the sound "W" as example below:

Example: $\underline{T} w$ $<\quad \mathrm{T} \underline{a u}$ Change of "S" to sound " $Z$ " as discussed below:

The word Maniz is a replacement of the word Manis. To make slang language the teenagers change the sound " $S$ " to the sound " $Z$ " as example below:

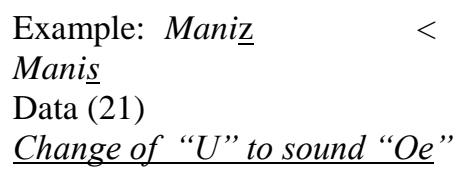

The word Imoet is a replacement of the word Imut. To make slang language the teenagers change the sound " $U$ " to the sound "Oe" as example below:

\section{Example: Imoet \\ Im $\underline{u}$}

The next way of forming slang language that is done by the teenagers is “Adoption of Basic Word". The analysis can be described from the discussion below:
Data (22)

Adoption of Basic Word

The words Binggow and Bingits are formed from the word Banget. These words are used to express or to describes something.

\section{Example: Qmu Hebat binggow \\ $=\quad$ Qmu cantik bingits}

The word Cemengut is formed from the word Semangat. This word is used to support someone to do something hard

Example: Cemengut ya kakak

= Semangat ya kakak

The word Jehong is formed from the word Jahat. This word is used to express someone's character

Example: Qmu jehong ya =

Kamu Jahat ya

The word Keles is formed from the word

Kali. This word is used to express or to emphasize about someone's opinion. This word is not used for counting or meas multiple.

Example: Iya tau Keles =

Iya, saya sudah tahu tentang itu

* 2 keles $2=4$ (Unaccepted)

The next data displayed is the forms of slang language that are made from the "English and English - Indonesia Abbreviation”. The way of theirs formulated can be seen from the discussion below:

\section{Data (23)}

"English Language Abbreviation"

The word $\underline{C O P A S}$ comes from the original of English language words of COPY PASTE. It combines to make slang language. The combination happened in the initial each syllable of words. $\underline{C O}$ and $\underline{P A S}$.

The word $O T W$ comes from the original of English language words of $\underline{O N T H E}$ $\underline{W A Y}$. It combines to make slang language. The combination happened in the initial each letter of words. $\underline{O, T}$ and $\underline{W}$.

The word $O M G$ comes from the original of English language words of $\mathrm{OHMY}$ $\underline{G O D}$. It combines to make slang language. The combination happened in the initial each letter of words. $\underline{O, M}$ and $\underline{G}$. 
The word $\underline{G W S}$ comes from the original of English language words of GET WELL $\underline{S O O N}$. It combines to make slang language. The combination happened in the initial each letter of words. $\underline{G, W}$ and $\underline{S}$.

The word INTRO comes from the original of English language words of INTRODUCE. It takes two initial syllables of word to make slang language.

Data (24)

"English - Indonesia Abbreviation

The word LOLA comes from the original of English - Indonesia language words

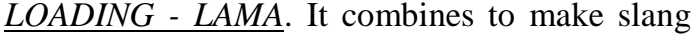
language. The combination happened in the initial each syllable of English - Indonesia words. $\underline{L O}$ and $\underline{L A}$.

The word WAK - SELFIE comes from the original of English - Indonesia regional language words of $A W A K$ and SELFIE. Awak is a word that is mostly used by Sumatra people refers to the first or third singular person. It combines to make slang language.

The next example of slang language is made by "Citation". Citation word means the use of slang language which is taken from other regional language. It can be seen from the discussion below:

Data (25)

Citation

The word Loe comes from the Jakarta language that refers to $\underline{\mathrm{Kamu}}$ or $\underline{\text { You }}$ in English language. This word is adopted by BatamTeenagers to use in their communication

The word $\underline{\text { Gue }}$ also comes from the Jakarta language that refers to $\underline{S a y a}$ or $\underline{I}$ in English language. This word is adopted by BatamTeenagers to use in their communication

The word Die comes from the Jakarta language that refers to $\underline{\mathrm{Dia}}$ or $\underline{\mathrm{He}}$ or She in English language. This word is adopted by BatamTeenagers to use in their communication.
The last way of making slang language that done by teenagers in their communication is “ New Construction”. The words “ New Construction " here mean the slang language allegedly that are formed under arbitrariness. No relation of making these slang language form to other basic languages including Indonesia, English or Regional language. It can be seen from the example below:

Data (26)

New Construction

Nyanting is slang language that refers to the meaning of Pinjam or borrow. No correlation form of pronunciation between the word nyanting and pinjam. Relat is slang language that refers to the meaning of Jadian or make a relationship with boyfriend or girlfriend. No correlation form of pronunciation between the word Relat and Jadian.

$\underline{B a d i}$ is slang language that refers to the meaning of Orang GIla or a crazy man. No correlation form of pronunciation between the word Badi and Orang Gila.

Kepo is slang language that refers to the meaning of Pengen Tau or to know curiously. No correlation form of pronunciation between the word Kepo and to know curiously.

\subsubsection{Transformational Language}

Transformational language is a slang language used by teens in the 80's. the transformational language used at that time was very rigid and not as varied as slang in this period. the formation of transformational language as slang language can be seen in the discussion below. In constructing a transformational language as slang in teenagers' community in 90 s era, the teenagers insert the formula of $G a, G i, G u, G e$, and $G o$ in basic form of the word which is associated to the last sound of each syllable. In the other word, the inserting of formula $\mathrm{Ga}, \mathrm{Gi}, \mathrm{Gu}, \mathrm{Ge}$, Go depands on the existence of final syllable sound for each word. The phenomenon of tranformational language 
construction can be devided into some formula, they are:

Data (27)

$G a, G i, G u, G e$, Go formula after single vowel sound syllable

Kagamugu sugukaga sagamaga agakugu

Kamu suka sama aku)

(You like me)

The sentence above describes the use of transformational language using $G a, G i, G u, G e$,

Go formula to form the slang language with the final single sound of vowel.

- The word "kagamugu" means "ka-mu" which is inserted the formula "ga" in the end of each syllable.It is added by "ga" syllable because the final syllable for this word is single vowel sound " $A$ ". Each syllable which is ended by single vowel sound must be transformed by "ga-gi-guge-go" formula. $(\mathrm{ka}-\mathrm{ga}-\underline{\mathrm{mu}}$-gu = kamu)

- The word "sugukaga" means "suka" whichs is transformed by syllable "ga and gu" after syllable of each word. "su" becomes $\underline{\text { su-gu }}$ and "ka" becomes kaga.(su-gu-ka-ga)

- The word "sagamaga" comes from the original word "sama". The word sama is inserted by formula " $g a$ and $g u$ " because each syllable of the word ended by single vowel syllabel sound "A and U". The syllable " $S a$ " becomes $s a-g a$ and " $m a$ " becomes ma-ga.

- The word "agakugu" comes from the original word "aku". The original word $a k u$ is inserted by formula" $g a$ and $g i$ " because each syllable of the word ended by single vowel sound "A and i". The syllable " $a$ " becomes $a$-ga and syllable " $k u$ " becomes ku-gu. (a-ga-ku-gu = aku)

Data (28)

$G a / G, G i, G u, G e$, Go formula before dipthong sound syllable

Agandagai_kagamugu_ pagakagai

Segepegedaga agakugu lagambagai

(Kalau kamu pakai sepeda aku lambai)

(if you use bicycle I will wave my hand)

The sentence above describes the use of transformational language using $G a, G i, G u, G e$,

Go formula to form the slang language after dipthong syllable.

- The word "agandagai" comes from the original word of "andai". The final syllable of the word is is dipthong "ai". To make slang the formula "ga" is inserted before the sound of dipthong not before syllable. an-dai becomes a-ganda-ga-i.

- The word "pagakagai" originally comes from the word 'pakai'. The final syllable of the word pakai is "ai" dipthong. To transform the word pakai becomes slang the teenagers insert the formula "ga" before the dipthong. pakai finally becomes "pa-ga-ka-ga-i".

- The word "lagambagai" also one of the slangs words formed by adding the formula "ga" in the original word of "lambai". To make the word Baloi becomes slang, the teenagers transform the formula "ga" before syllable of dipthong and finally becomes "la-ga-mba-ga-i”

Data (29)

$\mathrm{G} a, G i, G u, G e, G o$ formula before last consonant sound

Kagapagan kagamugu magakagan magalagam sagamaga igikagan (kapan kamu makan malam pakai ikan) (When you have a dinner by fish)

The tranformational process of making slang language before last consonant sound the same as the construction of slang before dipthong. The formula $g a, g i, g u, g e, g o$ added before consonant sound as described below:

The word "kagapagan" means "kapan" which is added the formula "ga" because in the first syllable of word "ka" is ended by single vowel sound "a" and becomes " kaga". The last syllable is "pan" with final sound consonant " $n$ ". To form slang formula is put before consonant " $n$ " and becomes "pa-ga-n"

- The slang word "magalagam" originally comes from the standart word "malam". It becomes slang when formula ga, gi,gu,ge,go inserted after each vowel syllable sound and before syllable final consonant sound. The syllable "lam" from "ma-lam" is inserted the formula "ga" before "m" as final sound of syllable. The transformational words becomes "ma-gala-ga-m”.

- The word slang "magakagan" is transformed from the original word "makan". The formula "ga" is embeded after syllable "ma". For the final sound of consonant the formula "ga" is added and 
put before final consonant sound ' $\mathrm{m}$ ' and becomes "ka-ga-n".

- The same process also happened in the construction of "igikagan". This word originally comes from the basic word of "ikan". To make it slang the formula "gi" is embedded after the syllable "i" and add sound "ka" (i-gi-ka), and the syllable "ka" is followed by the formula "ga" and finally becomes (i-gi-ka-ga-n)

Data (30)

$G a, G i, G u, G e$, $G o$ formula for cluster consonant

Sagayaga tagaragaktigir uguagang tagaraganspogortagasigi

Saya traktir uang transportasi

(I give a transportation fee)

The transformational word "tagaragaktigirigir" is from the standard word "traktir". For the initial cluster consonant such as "tr" the transformational word is differently cosntructed from other forms. To make slang word the initial or final cluster consonant must be seperated by "a, i , u ,e or o" and becomes "T- $a+$ ga". The next clusters consonant sound " $\mathrm{r}$ " is also embedded by a, i, u, e, and o, so becomes " $\mathrm{R}-a+$ ga- $\mathrm{k}$ ". The last syllable is "tir" is embedded by formula"g" and finally becomes "ti-gi-r" $(t+a-g a-r+a-g a-$ $k$-ti-gi-r).

The second example of transformational language as slang can be seen from the word "tagaraganpogortagasisgi". This words originally comes from the standart language "transportasi". To make it slang the teenagers insert the vowel sound $a, i, u$, $\mathrm{e}$, and o after initial consonant cluster. The sound " $T$ " in the first consonant must be added by vowel "a" becomes "ta+ga". The second consonant also be added by "a" becomes "ra+ga.

Data (31)

$G a, G i, G u, G e, G o$ formula for "ng" sound

Magalagang nagasigib ogoragang igitugu

(how poor his condition)

The word slang "magalagang" is transformed from the original word "malang". The formula "ga" is embeded after syllable "ma". For the final sound of consonant the formula "ga" is added and put before final sound "ng' and becomes "ma-ga-la-ga-ng".

The word slang "ogoragang" is transformed from the original word "orang". The formula "go" is embeded after the sound "o". For the final sound of consonant the formula "ga" is added and put before final sound "ng' and becomes "o-go-ra-ga-ng".

\subsubsection{Perspective of Colloquail, Slang and Transformational Language Use}

The non-standard language uses such as colloquial, slang and Transformational have different backgrounds in the reason of their use. Each language has different times and users in the community. To see how the perspective of colloquial, slang and Transformational languages can be seen in the table below:

Table 4.1 Perspective of Colloquial, Slang and Transformational Language Use

\begin{tabular}{|c|c|c|c|c|}
\hline No & $\begin{array}{c}\text { Reason } \\
\text { Items }\end{array}$ & $\begin{array}{c}\text { Slang } \\
\text { (amoun } \\
\text { t) }\end{array}$ & $\begin{array}{c}\text { Colloq } \\
\text { uail } \\
\text { (amou } \\
\text { nt) }\end{array}$ & $\begin{array}{c}\text { Transformati } \\
\text { onal) } \\
\text { (amount) }\end{array}$ \\
\hline 1 & $\begin{array}{l}\text { Ikut- } \\
\text { Ikutan } \\
\text { Teman } \\
\text { (Followe } \\
\text { rs) }\end{array}$ & $\begin{array}{c}(\mathbf{4}) \\
10.25 \\
\%\end{array}$ & $\begin{array}{c}(\mathbf{5}) \\
17.85 \\
\%\end{array}$ & $\begin{array}{c}(\mathbf{2}) \\
11.11 \%\end{array}$ \\
\hline 2 & $\begin{array}{l}\text { Mengikut } \\
\text { in zaman } \\
\text { (Era } \\
\text { Adaptati } \\
\text { on) } \\
\end{array}$ & $\begin{array}{c}(\mathbf{5}) \\
12.82 \\
\%\end{array}$ & 0 & 0 \\
\hline 3 & $\begin{array}{l}\text { Biar } \\
\text { dibilang } \\
\text { keren } \\
\text { dan Gaul } \\
\text { (Being a } \\
\text { cool } \\
\text { man) }\end{array}$ & $\begin{array}{c}\mathbf{( 1 2 )} \\
30.76 \\
\%\end{array}$ & 0 & $\begin{array}{c}(3) \\
16.66 \%\end{array}$ \\
\hline 4 & $\begin{array}{l}\text { Mudah } \\
\text { berkomu } \\
\text { nikasi } \\
\text { dengan } \\
\text { teman/le } \\
\text { bih cepat }\end{array}$ & $\begin{array}{c}\text { (4) } \\
10.25 \\
\%\end{array}$ & $\begin{array}{c}(\mathbf{1 3}) \\
46.42 \\
\%\end{array}$ & 0 \\
\hline 6 & $\begin{array}{l}\text { Biar } \\
\text { tenar } \\
\text { Being a } \\
\text { familiar) }\end{array}$ & $\begin{array}{c}(7) \\
17.94 \\
\%\end{array}$ & 0 & 0 \\
\hline 7 & $\begin{array}{l}\text { Kebiasaa } \\
n \\
\text { (habit) }\end{array}$ & $\begin{array}{c}\mathbf{( 1 )} \\
1.68 \%\end{array}$ & $\begin{array}{c}(\mathbf{1 0}) \\
35.71 \\
\% \\
\end{array}$ & $\begin{array}{c}(\mathbf{1}) \\
5,55 \%\end{array}$ \\
\hline 8 & $\begin{array}{l}\text { Lucu- } \\
\text { lucuan } \\
\text { (having } \\
\text { Fun) }\end{array}$ & $\begin{array}{c}(\mathbf{1}) \\
2.56 \%\end{array}$ & $\mathbf{0}$ & 0 \\
\hline 9 & $\begin{array}{l}\text { Merahas } \\
\text { iakan } \\
\text { sesuatu } \\
\end{array}$ & $\begin{array}{c}\text { (3) } \\
7.69 \%\end{array}$ & 0 & $\begin{array}{c}(\mathbf{1 2}) \\
66.66 \%\end{array}$ \\
\hline
\end{tabular}




\section{(Hiding}

somethin

g)

\begin{tabular}{cccc}
\hline $\begin{array}{c}\text { Total } \\
\text { Comments }\end{array}$ & 39 & 28 & 18 \\
\hline $\begin{array}{c}\text { Total } \\
\text { Respondent }\end{array}$ & 15 & 15 & 15 \\
\hline
\end{tabular}

Based on the recapitulation of the perspectives on the use of colloquial language, slang language and transformational language, it can be concluded that the qolooquial speakers intend to get ease in communicating among themselves. This is seen from the response of $46 \%$. The colloquail language as a habit is delivered around $35.71 \%$. Teenagers use slang because they want to show their existence to others. This can be seen from the percentage of use which is $30.76 \%$. For transformational language, its use is intended to hide something from other people. This was responded to by $66.66 \%$

\section{CONCLUSION}

The phenomenon of non-standard language usages such as colloquial, slang and transformational language in the community cannot be separated from the variation of language owned by each community group or certain community. The use of non-standard language shows the dynamics of different languages in the

life of society. The use of nonstandard languages such as colloquial, slang and transformational in society can be seen from the different shapes, context, and perspective of its use. Comparison of forms, contexts, and perspectives of colloquial language use, slang, and transformational researchers collect data and perform in-depth analysis process and can be determined, among others.
From the non-colloquial standard language form, slang and transformational mentioned above can be concluded that the variation of non-standard language usage has a different pattern of formation different. This difference is affected by the user's background, the situation or the period of use of those languages. The colloquial language usage context is more influenced by the habitual aspects heard by speakers in their environment such as at home, in markets, playgrounds, and certain other events. For context slang languages, its use is influenced by the juvenile community environment where users only on the uses level 12 to 19 years. Slang language is used as a form of adolescent existence in their community. Transformational language is a long slang language that was present in the $80 \mathrm{~s}$ where the context of its use was influenced by the desire to hide speech to people who were not from their groups like parents and strangers.

\section{REFERENCE}

Afzali, K. (2011). The Address Forms of Spouses in Different Social Strata in Iran and Its Sociolinguistic Implications. International Journal of Linguistics, Vol. 3 No.(ISSN 1948-5425), 1-9. https://doi.org/10.5296/ijl.v3i1.721

Chetia, B. (2015). Slangs and Gender-A Sociolinguistic Perspective. International Journal of Technical Research and Applications, Vol.4. No.(Issue 18 (June, 2015)), PP. 43-46. Retrieved from http://www.ijtra.com/special-issueview/slangs-and-gender-a-sociolinguisticperspective.pdf

Debora, I. (2013). The Using of Casual Style in ELT For Young Learners ( Sociolinguistics Perspectives ). Advances in Language and Literary Studies, Vol.4 No.1(Advanced in Language and Literary Studies), 1-5. https://doi.org/10.7575/aiac.alls.v.4n.1p.1 24 
Epoge, N. K. (2012). Slang and Colloquialism in Cameroon English Verbal Discourse. International Journal of Linguistics, Vol 4, No.(International Journal of Linguistics), Hal.130-145. https://doi.org/http://dx.doi.org/10.5296/ij 1.v4i1.1414

Estellés-arguedas, M. (2015). ScienceDirect Expressing evidentiality through prosody? Prosodic voicing in reported speech in Spanish colloquial conversations. Journal of Pragmatics, 85, 138-154.

https://doi.org/10.1016/j.pragma.2015.04. 012

Fasya, M. (2013). Variable Sosial Sebagai Penentu Penggunaan Slang Makian dalam Bahasa Indonesia. Masyarakat Linguistik Indonesia, 1, 81-102. Retrieved from http://www.academia.edu/6649221/Jurnal _Linguistik_Indonesia_Tahun_ke31_Nomor_1

Fitch-romero, R., \& Rodríguez-sánchez, I. (2013). Comparison of Colloquial Terms in Two Mexican Spanish Dictionaries : an Analysis Based on Examples of Use . Procedia - Social and Behavioral Sciences, 95, 308-316. https://doi.org/10.1016/j.sbspro.2013.10.6 52

Galván, B. E. (2015). “ Trapicheando ” on Baltimore , s Corners A Semantic Analysis of The Wire, s Slang Terminology and its Translation. Procedia - Procedia Computer Science, 212, 218-225. https://doi.org/10.1016/j.sbspro.2015.11.3 36

Gemilasari. (2013). An Analysis of Word Formation of Slang Words Found In. English Language and Literature EJournal, volume 3, (September ISSN 23023546), 142-148. Retrieved from http://onesearch.id/Record/IOS242.article2403 ?widget=1\&repository_id=3369

Inayati, A. (2014). Flouting Maxims In Particularized Conversational Implicature. International Journal of Language Learning and Applied Linguistics World (IJLLALW), 6(July EISSN: 2289-2737 \& ISSN: 2289-3245), 53-61. Retrieved from Flouting Maxims in Particularized Conversational Implicature

Litosseliti, L. (2010). Research Method in Linguistics (third edit). New York: Continuum International Publishing Group. Retrieved from www.continuumbooks.com

Matsumoto, K., Akita, K., Keranmu, X., Yoshida, M., \& Kita, K. (2014). Extraction Japanese slang from weblog data based on script type and stroke count. Procedia - Procedia Computer Science, 35, 464-473. https://doi.org/10.1016/j.procs.2014.08.12 7

Ong, J., Liaw, H., Aina, N., Ahmad, D., Johari, Z., \& Lumpur, K. (2013). Language Usage of Jargon and Slang in Strategic Studies. Australian Journal of Basic and Applied Sciences, 7(4), 661-666. Retrieved from https://www.researchgate.net/profile/Jessi ca_Ong_Hai_Liaw/publication/28149309 3_Language_Usage_of_Jargon_and_Slan g_in_Strategic_Studies/links/55eb16b308 aeb6516267734a.pdf

Pal, A. R., \& Saha, and D. (2013). Detection of Slang Words in e-Data using semi Supervised Learning. International Journal of Artificial Intelligence \& Applications (IJAIA), Vol. 4, $\mathrm{No}$ (International Journal of Artificial Intelligence \& Applications (IJAIA)), 4555 . 10.5121/ijaia.2013.4504 https://doi.org/DOI :

Pishghadam, R. (2011). Delving into Speech Act of Suggestion: A Case of Iranian EFL Learners. International Journal of Bussiness and Social Science, Vol.2 No. (in International Journal of Bussiness and Social science), 152-160. Retrieved from http://profdoc.um.ac.ir/paperabstract-1023036.html

Preece, S. (2015). “ They ain' t using slang ": Working class students from linguistic minority communities in higher education. Linguistics and Education, 31, 260-275.

https://doi.org/10.1016/j.linged.2014.10.0 03

Sato, Y., \& Kim, C. (2012). Radical pro drop and the role of syntactic agreement in 
Colloquial Singapore English. Lingua, 122(8), 858-873. https://doi.org/10.1016/j.lingua.2012.02.0 06

Suhardianto. (2016). A Phenomena Of Teenagers' Language Use In Batam: Language Variation. Ellite, 01 ISSN 25(November), 56-66.

Trask, R. . (2001). A Student's Dictionary of Language and Linguistics (second edi). London: Oxfod University Press.

Zhou, Yanchun, Y. F. (2013). A Sociolinguistic Study of American Slang. Theory and Practice in Language Studies, Vol. 3, $N o$ (Theory and practice in Language studies), 2209-2213. Retrieved from http://www.academypublication.com/issu es/past/tpls/vol03/12/08.pdf 
DOI: 10.33884/basisupb.v6i1

e-ISSN. 2406 - 9809 p-ISSN. 2527 - 8835
Jurnal Basis Vol. 6 No.l April 2019

English Department - Putera Batam University. 